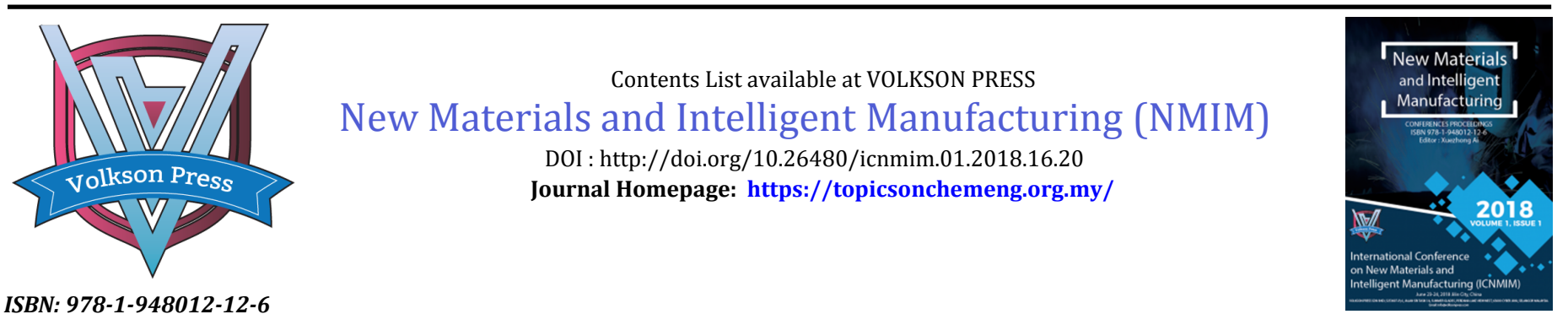

\title{
A NEW SINGLE-COMPONENT CA20AL26MG3SI3068:DY3+, EU3+ POTENTIAL PHOSPHOR FOR WHITE-LIGHT EMITTING DIODES: LUMINESCENCE PROPERTIES, ENERGY TRANSFER AND MULTICOLOR LUMINESCENCE
}

\author{
Bo Yuan', Yanhua Song' ${ }^{2}$, Weidong Wang', Haifeng Zou ${ }^{2}$, Li Kong ${ }^{1}$, Chuanbo Dai ${ }^{*}$ \\ ${ }^{1}$ College of Petrochemical Engineering, Jilin Institute of Chemical Technology, Jilin 132000, PR China \\ ${ }^{2}$ College of Chemistry, Jilin University, Changchun 130012, PR China \\ *Corresponding author email: hgxy356900963@sohu.com
}

This is an open access article distributed under the Creative Commons Attribution License, which permits unrestricted use, distribution, and reproduction in any medium, provided the original work is properly cited

\section{ARTICLE DETAILS}

Article History:

Received 26 June 2018 Accepted 2 July 2018

Available online 1 August 2018

\section{ABSTRACT}

In this study, novel single-component $\mathrm{Ca}_{20} \mathrm{Al}_{26} \mathrm{Mg}_{3} \mathrm{Si}_{3} \mathrm{O}_{68}: \mathrm{Dy}^{3+}, \mathrm{Eu}^{3+}$ phosphor has been successfully prepared by high temperature solid state reaction. The crystal structure, luminescent property, energy transfer and multicolor emission behavior were investigated in detail. The structure was characterized by X-ray diffraction (XRD) and the results indicate that the as-prepared samples are of pure orthorhombic phase of $\mathrm{Ca}_{20} \mathrm{Al}_{26} \mathrm{Mg}_{3} \mathrm{Si}_{3} \mathrm{O}_{68}$ and $\mathrm{Dy}^{3+}$ and $\mathrm{Eu}^{3+}$ are totally incorporated into the host lattice of $\mathrm{Ca}_{20} \mathrm{Al}_{26} \mathrm{Mg}_{3} \mathrm{Si}_{3} \mathrm{O}_{68}$. The $\mathrm{Dy}^{3+}$ or $\mathrm{Eu}^{3+}$ single doped samples exhibit strong yellow and red emissions, originating from the ${ }^{4} \mathrm{~F}_{9 / 2} \rightarrow{ }^{6} \mathrm{H}_{13 / 2}$ transition of $\mathrm{Dy}^{3+}$ and the ${ }^{5} \mathrm{D}_{0} \rightarrow{ }^{7} \mathrm{~F}_{\mathrm{J}}(\mathrm{J}=0,1,2,3)$ transitions of $\mathrm{Eu}^{3+}$ and the optimal concentration of $\mathrm{Dy}^{3+}$ and $\mathrm{Eu}^{3+}$ ions in $\mathrm{Ca}_{20} \mathrm{Al}_{26} \mathrm{Mg}_{3} \mathrm{Si}_{3} \mathrm{O}_{68}$ were determined to be $5 \mathrm{~mol} \%$ and $11 \mathrm{~mol} \%$, respectively. Meanwhile, the energy migration from $\mathrm{Dy}^{3+}$ to $\mathrm{Eu}^{3+}$ in co-doping samples has been confirmed by the excitation and emission spectra and the process was reported in detail. Based on the energy transfer, under the excitation of $344 \mathrm{~nm}$, the emitting color can change from yellow to orange red by adjusting the relative doping concentration of $\mathrm{Dy}^{3+}$ and $\mathrm{Eu}^{3+}$ ions, indicating that the phosphors $\mathrm{Ca}_{20} \mathrm{Al}_{26} \mathrm{Mg}_{3} \mathrm{Si}_{3} \mathrm{O}_{68}: \mathrm{Dy}^{3+}$, Eu ${ }^{3+}$ with tunable multicolor emissions may have potential application in pc-white LEDs.

\section{KEYWORDS}

$\mathrm{Ca}_{20} \mathrm{Al}_{26} \mathrm{Mg}_{3} \mathrm{Si}_{3} \mathrm{O}_{68}: \mathrm{Dy}^{3+}, \mathrm{Eu}^{3+}$, Energy transfer, Multi-color emission, WLED

\section{INTRODUCTION}

In recent years, with the issues of the energy and environmental becoming increasingly prominent, white-light-emitting diodes (WLEDs) have been widely studied and used in the lighting and display fields due to their special superiorities of saving energy, long lifetime, reliability, environmental friendly and so on [1-3]. Nowadays, in several ways to assemble WLEDs, the most prevalent strategy is based on YAG: $\mathrm{Ce}^{3+}$ as a kind of broadband yellow phosphor coated on a blue InGaN chip, however, because of the innate lack of red-emission, this combination usually has the problems of low color rendering index (CRI) and high correlated color temperature (CCT) [4,5]. Another method is to combine n-UV LED with blue, green and red phosphors which is considered to be more stable and flexible. But the shortcomings of the reabsorption of blue light by red and green phosphors appear, resulting in lower external quantum luminous efficiency of the resulting $w$-LEDs. Based on this situation, the single-phase phosphor-converted UV WLEDs can overcome these drawbacks because it possesses some surprisingly favorable properties, such as tunable CIE chromaticity coordinates, excellent $\mathrm{R}_{\mathrm{a}}$ values and color stability, etc. Therefore, an increasing number of researchers have paid attention to studying and developing full-color emitting single-phase phosphors [6$10]$.

Co-doping sensitizer and activator into the same host based on the energy transfer is one of the approaches to produce white light or color-tunable emissions from single phase phosphors. Many materials can be the matrix, such as phosphates, lanthanide-doped oxides and fluorides, among these materials, the aluminosilicate (such as $\mathrm{Ca}_{20} \mathrm{Al}_{26} \mathrm{Mg}_{3} \mathrm{Si}_{3} \mathrm{O}_{68}$ ) is regarded as an interesting and highly-focused host luminescent material for rare earth ions emission due to its excellent chemical and thermal stability and proper crystal field to promote luminescence [11-13]. Among various RE trivalent ions, dysprosium ( $\mathrm{Dy}^{3+}$ ) is well known for its emission in the yellow and blue regions corresponding to the ${ }^{4} \mathrm{~F}_{9 / 2} \rightarrow{ }^{6} \mathrm{H}_{13 / 2}$ and ${ }^{4} \mathrm{~F}_{9 / 2} \rightarrow{ }^{6} \mathrm{H}_{15 / 2}$ transitions, respectively. If the ratio of blue to yellow emission is appropriate, white emission can be attained by using $\mathrm{Dy}^{3+}$ ions alone $[14,15]$. But the combination of blue and yellow emissions lacks the red part, the $\mathrm{Eu}^{3+}$ that emits red light corresponding to the ${ }^{5} \mathrm{D}_{0} \rightarrow{ }^{7} \mathrm{~F}_{2}$ transition can be introduced [16]. Thereby, it is feasible to produce $\mathrm{Dy}^{3+}$ and $\mathrm{Eu}^{3+} \mathrm{co}-$ activated white light or tunable color phosphors. At present, Dy ${ }^{3+}$ and $\mathrm{Eu}^{3+}$ co-doped single-phase phosphors have been vigorously studied and reported, such as $\mathrm{Na}_{3} \mathrm{Gd}\left(\mathrm{PO}_{4}\right)_{2}, \quad \mathrm{BaLa}_{2} \mathrm{WO}_{7}, \quad \mathrm{BaCa}_{2} \mathrm{Y}_{6} \mathrm{O}_{12}$ and $\mathrm{Ca}_{2} \mathrm{La}_{8}\left(\mathrm{GeO}_{4}\right)_{6} \mathrm{O}_{2}[1,8,17,18]$. However, their work have solely focused on the multicolor emissions based on the energy transfer $[19,20]$. Hence, different with previous studies, by taking into consideration the characteristic emissions of dysprosium and europium ions, it is expected that multicolor emissions could be achieved in $\mathrm{Ca}_{20} \mathrm{Al}_{26} \mathrm{Mg}_{3} \mathrm{Si}_{3} \mathrm{O}_{68}$ system by adjusting different excitation wavelengths and properly designed activator contents. $\mathrm{Dy}^{3+}-\mathrm{Eu}^{3+}$ co-doping aluminosilicate $\mathrm{Ca}_{20} \mathrm{Al}_{26} \mathrm{Mg}_{3} \mathrm{Si}_{3} \mathrm{O}_{68}$ single-phase phosphor is novel and its synthetic process is simple and convenience. Meanwhile, the luminosity is ideal and energy transfer in $\mathrm{Ca}_{20} \mathrm{Al}_{26} \mathrm{Mg}_{3} \mathrm{Si}_{3} \mathrm{O}_{68}: \mathrm{Dy}^{3+}, \mathrm{Eu}^{3+}$ have not been yet investigated up to now.

In this work, we first reported a novel single phase $\mathrm{Ca}_{20} \mathrm{Al}_{26} \mathrm{Mg}_{3} \mathrm{Si}_{3} \mathrm{O}_{68}$ : $\mathrm{Dy}^{3+}$, $\mathrm{Eu}^{3+}$ phosphor prepared through a simple high temperature solid state method. The crystal structure, luminescence properties, energy transfer and color tunable luminescence of the phosphors were studied. The energy transfer from $\mathrm{Dy}^{3+}$ to $\mathrm{Eu}^{3+}$ in $\mathrm{Ca}_{20} \mathrm{Al}_{26} \mathrm{Mg}_{3} \mathrm{Si}_{3} \mathrm{O}_{68}$ (following for short as CAMSO) system were investigated in detail and the mechanisms are also discussed for the energy transfer behavior. Finally, the results indicate that this phosphor can be effectively excited by UV (about $344 \mathrm{~nm}$ ) 
light and emit visible light from yellow to orange red by altering the concentration ratio of $\mathrm{Dy}^{3+}$ and $\mathrm{Eu}^{3+}$, and it may have potential applications in white LEDs as a promising single-phase color-tunable phosphor.

\section{EXPERIMENTAL}

A series of single-phased CAMSO: $\mathrm{Dy}^{3+}, \mathrm{Eu}^{3+}$ phosphors were synthesized by high temperature solid-state reaction. The raw materials $\mathrm{CaCO}_{3}$ (A.R.), $\mathrm{Al}_{2} \mathrm{O}_{3}$ (A.R.), $\mathrm{MgO}$ (A.R.), $\mathrm{SiO}_{2}$ (A.R.) were obtained from the Beijing Chemical Reagent Research Institute of China and spectrographically pure $\mathrm{Dy}_{2} \mathrm{O}_{3}(99.95 \%), \mathrm{Eu}_{2} \mathrm{O}_{3}$ (99.99\%) were supplied by Shanghai Yuelong NonFerrous Metals Limited of China. These raw reactants were quantified based on the stoichiometric molar ratio and then mixed in an agate mortar by grinding. The powder after mixing was placed in a small corundum crucible and sintered in a tubular furnace at $1380{ }^{\circ} \mathrm{C}$ for $2 \mathrm{~h}$ in air atmosphere, and slowly cooled down to room temperature.

The powder X-ray diffraction patterns (XRD) were recorded by powder $\mathrm{X}$-ray diffractometer (RigakuD/Max-BII), using $\mathrm{Cu} \mathrm{K \alpha}$ radiation. The excitation and emission spectra were recorded by a Jobin Yvon FluoroMax-4 equipped with a $150 \mathrm{~W}$ xenon lamp as the excitation source. All the experiments were performed at room temperature.

\section{RESULTS AND DISCUSSION}

The crystal structure of CAMSO belongs to a orthorhombic space group with a relatively large unit cell, and the lattice parameters are $a=27.64 \AA$, $\mathrm{b}=10.802 \AA, \mathrm{c}=5.124 \AA$ and $\mathrm{V}=1529.9 \AA^{3}$, respectively. Figure 1 represents the crystal structure and cation polyhedral arrangements of CAMSO. The structure contains twelve $\mathrm{AlO}_{4}$, twelve $(\mathrm{Mg}, \mathrm{Al}) \mathrm{O}_{4}$ and eight $(\mathrm{Al}, \mathrm{Si}) \mathrm{O}_{4}$ tetrahedra with mean $\mathrm{M}-\mathrm{O}(\mathrm{M}=\mathrm{Mg} / \mathrm{Al}, \mathrm{Si} / \mathrm{Al}$, or $\mathrm{Al})$ distances of $1.76,1.79$ and $1.71 \AA$, respectively. $\mathrm{AlO}_{4}$ and $(\mathrm{Al}, \mathrm{Si}) \mathrm{O}_{4}$ tetrahedra are linked through corners to form a network of five-membered rings, similar to those found in gehlenite and $5 \mathrm{CaO} .3 \mathrm{Al}_{2} \mathrm{O}_{3}$. These differ in the propagation of the fivemembered rings of $\mathrm{MO}_{4}$ tetrahedra. While in $\mathrm{Ca}_{20} \mathrm{Al}_{26} \mathrm{Mg}_{3} \mathrm{Si}_{3} \mathrm{O}_{68}, \mathrm{MO}_{4}$ tetrahedra are connected into infinite strips of five-membered rings in the b direction separated by chains of $(\mathrm{Mg}, \mathrm{Al}) \mathrm{O}_{4}$ tetrahedra, the fivemembered rings in the last two compounds extend into infinite networks. Twelve $\mathrm{Ca}^{2+}$ ions in $\mathrm{Ca}_{20} \mathrm{Al}_{26} \mathrm{Mg}_{3} \mathrm{Si}_{3} \mathrm{O}_{68}$ are coordinated by eight $\mathrm{O}^{2-}$, and eight $\mathrm{Ca}^{2+}$ by six $\mathrm{O}^{2-}$ anions [21].

In order to identify the composition and phase purity of as-prepared products, XRD measurements were carried out. Figure 2 shows the XRD patterns of CAMSO:Dy ${ }^{3+}, \mathrm{Eu}^{3+}$ phosphors with different $\mathrm{Dy}^{3+}$ and $\mathrm{Eu}^{3+}$ concentrations as well as the standard diffraction lines of $\mathrm{Ca}_{20} \mathrm{Al}_{26} \mathrm{Mg}_{3} \mathrm{Si}_{3} \mathrm{O}_{68}$ (JCPDS no.350133). It can be seen that all the diffraction peaks of these samples correspond to the JCPDS standard pattern (JCPDS no.350133) and no other phases or impurities appear. This implies that the pure phase powder was obtained and the $\mathrm{Dy}^{3+}$ and $\mathrm{Eu}^{3+}$ ions can be dissolved into this host without producing any other phase. The approximate ionic radii of $\mathrm{Dy}^{3+}(0.0908 \mathrm{~nm})$ and $\mathrm{Eu}^{3+}(0.0950 \mathrm{~nm})$ are all similar to that of $\mathrm{Ca}^{2+}(0.100 \mathrm{~nm})$ so the $\mathrm{Dy}^{3+}$ and $\mathrm{Eu}^{3+}$ ions preferably occupies the $\mathrm{Ca}^{2+}$ ions rather than $\mathrm{Mg}^{2+}(0.072 \mathrm{~nm})$ [22]. Some small shifts in the diffraction patterns relative to the standard diffraction pattern of JCPDS no. 35-0133 can be ascribed to the differences of ionic radius between $\mathrm{Ca}^{2+}$ and $\mathrm{Dy}^{3+}$ as well as $\mathrm{Eu}^{3+}$. When the larger $\mathrm{Ca}^{2+}(0.100 \mathrm{~nm})$ ions were substituted by the smaller $\operatorname{Dy}^{3+}(0.0908 \mathrm{~nm})$ ions in the phosphor, the diffraction peaks are slightly shifted to a higher degree, in accordance to the Bragg equation: $\lambda=2 \mathrm{~d} \sin \theta[23]$.

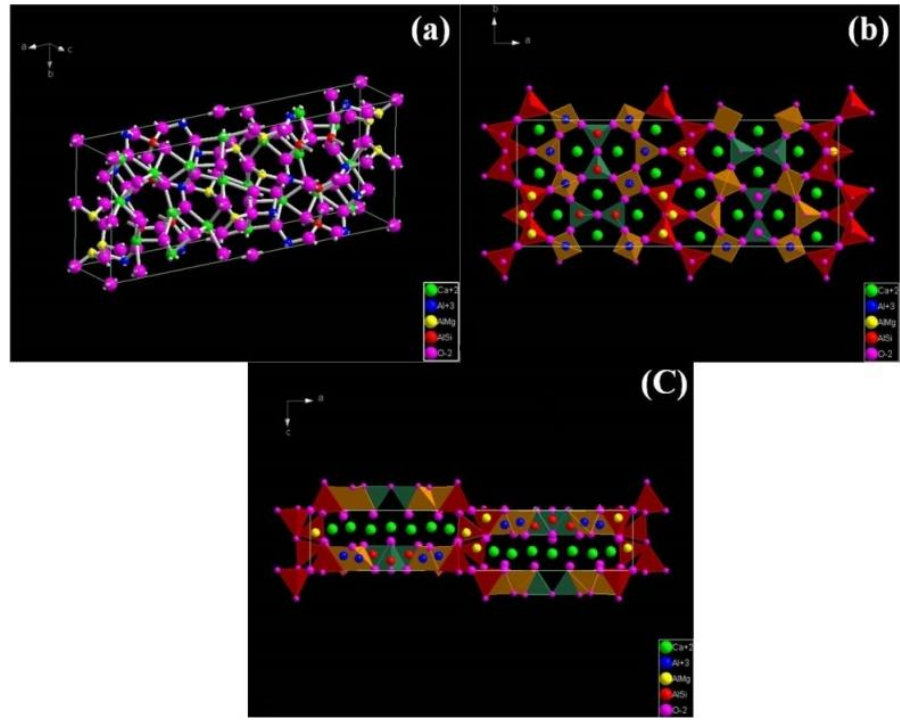

Figure 1: Crystal structure and cation polyhedral arrangements of CAMSO host

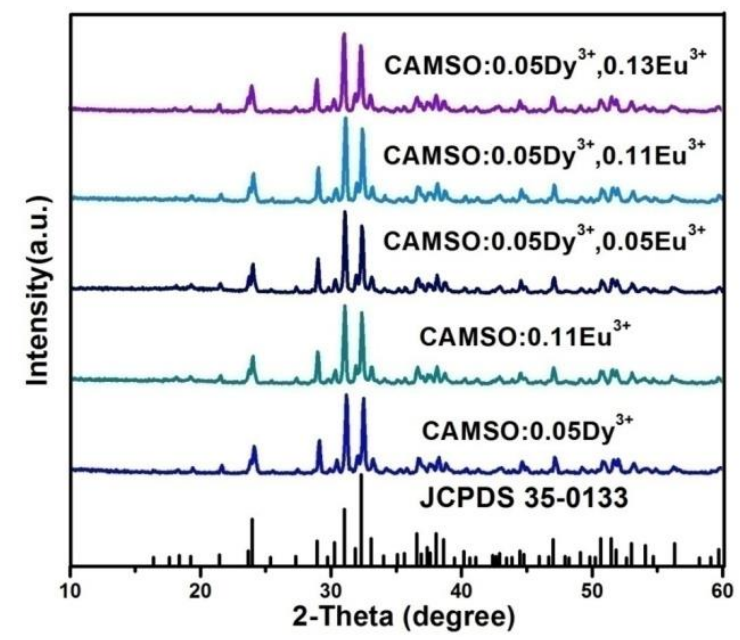

Figure 2: The XRD patterns of $\mathrm{Ca}_{20} \mathrm{Al}_{26} \mathrm{Mg}_{3} \mathrm{Si}_{3} \mathrm{O}_{68}: \mathrm{Dy}^{3+}$ $\mathrm{Ca}_{20} \mathrm{Al}_{26} \mathrm{Mg}_{3} \mathrm{Si}_{3} \mathrm{O}_{68}: \mathrm{Eu}^{3+}$ and $\mathrm{Ca}_{20} \mathrm{Al}_{26} \mathrm{Mg}_{3} \mathrm{Si}_{3} \mathrm{O}_{68}: \mathrm{Dy}^{3+}, \mathrm{Eu}^{3+}$ samples. The standard data of $\mathrm{Ca}_{20} \mathrm{Al}_{26} \mathrm{Mg}_{3} \mathrm{Si}_{3} \mathrm{O}_{68}$ (JCPDS no. 350133) is given as reference

The photoluminescence excitation and emission spectra of CAMSO:5\% Dy $^{3+}$ sample are displayed in Figure 3a. The excitation spectrum monitored with $475 \mathrm{~nm}$ emission $\left({ }^{4} \mathrm{M}_{21 / 2} \rightarrow{ }^{6} \mathrm{H}_{11 / 2}\right)$ is made up of a sharp excitation band at $344 \mathrm{~nm}$ (the strongest peak) and several other bands centered at 294, 320, 364 and $384 \mathrm{~nm}$, which are corresponding to the transitions of Dy ${ }^{3+}$ from the ground state ${ }^{6} \mathrm{H}_{15 / 2}$ to the excited state ${ }^{4} \mathrm{M}_{15 / 2},{ }^{4} \mathrm{D}_{7 / 2},{ }^{4} \mathrm{M}_{17 / 2},{ }^{4} \mathrm{I}_{11 / 2},{ }^{4} \mathrm{I}_{13 / 2}$, respectively. These excitation peaks indicate that the phosphor can forcefully absorb ultraviolet and blue light to obtain $\mathrm{Dy}^{3+}$ emission. Under the excitation of $344 \mathrm{~nm}$, the emission spectrum of CAMSO:5\% Dy $^{3+}$ covering the region from $450 \mathrm{~nm}$ to $700 \mathrm{~nm}$ contains two dominating emission bands, whose peaks are at 475 (blue) and $577 \mathrm{~nm}$ (yellow), attributing to the $\mathrm{Dy}^{3+}$ transitions of the magnetic dipole $\left({ }^{4} \mathrm{~F}_{9 / 2} \rightarrow{ }^{6} \mathrm{H}_{15 / 2}\right)$ and electric dipole transitions $\left({ }^{4} \mathrm{~F}_{9 / 2} \rightarrow{ }^{6} \mathrm{H}_{13 / 2}\right)$, respectively [24].

It can be seen that the emission at $475 \mathrm{~nm}$ lines is more intense than that at $577 \mathrm{~nm}$ lines, namely, the intensity of blue emission is greater than that of yellow emission. It is well known that the hypersensitive transition is strongly influenced by the outside environment surrounding $\mathrm{Dy}^{3+}$, and the magnetic dipole transition is insensitive to the crystal field around the Dy ${ }^{3+}$ ions. When Dy ${ }^{3+}$ is located at a low symmetry site (without inversion symmetry), the yellow emission is dominant in the emission spectrum; when $\mathrm{Dy}^{3+}$ is at a high symmetry site (with inversion symmetry), the blue emission is stronger than the yellow emission [25]. The stronger blue emission suggests that the site of $\mathrm{Dy}^{3+}$ ions has low symmetry, and this also can be confirmed by the crystal structure of $\mathrm{Ca}_{20} \mathrm{Al}_{2} \mathrm{Mg}_{3} \mathrm{Si}_{3} \mathrm{O}_{68}$ in Figure 1 . 

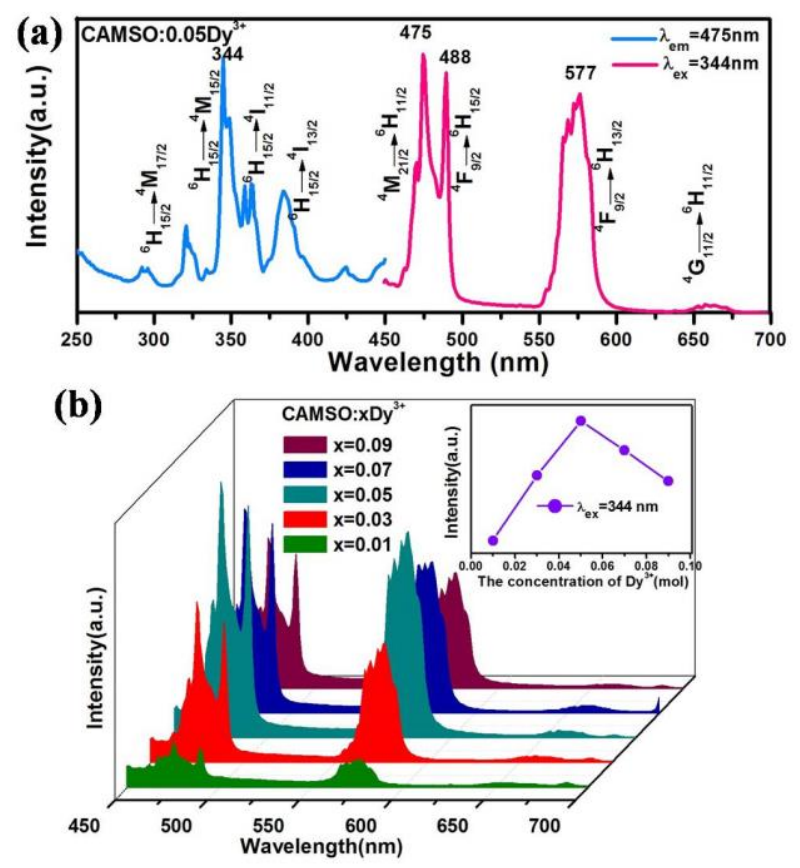

Figure 3: (a) The excitation and emission spectra of CAMSO:0.05 $\mathrm{Dy}^{3+}$ sample (b) the emission spectra of CAMSO: $\mathrm{xDy}^{3+}(\mathrm{x}=0.01-0.09)$ samples, the inset exhibits the intensity of Dy ${ }^{3+}$ ion with different $\mathrm{Dy}^{3+}$ concentrations

Figure $3 \mathrm{~b}$ illustrates the PL spectra of a series of CAMSO: $\mathrm{x} \% \mathrm{Dy}^{3+}$ with different $\mathrm{Dy}^{3+}$ concentrations under $344 \mathrm{~nm}$ excitation. It can be obviously observed that all emission bands show similar profiles with different relative intensities. Firstly, with the increasing of Dy ${ }^{3+}$ doping content, the emission intensity of the samples increases continuously, the best luminous concentration was at $\mathrm{x}=5 \%$, then decreases further when the doping content of Dy ${ }^{3+}$ ions exceeds $5 \mathrm{~mol} \%$ due to the concentration quenching effect. Therefore, the optimum concentration of $\mathrm{Dy}^{3+}$ was determined to be $5 \mathrm{~mol} \%$. The energy migration among the activator ions at high concentration triggers the concentration quenching. In this process, the loss of energy increases at a killer or quenching site, so the emission intensity decreases [26].

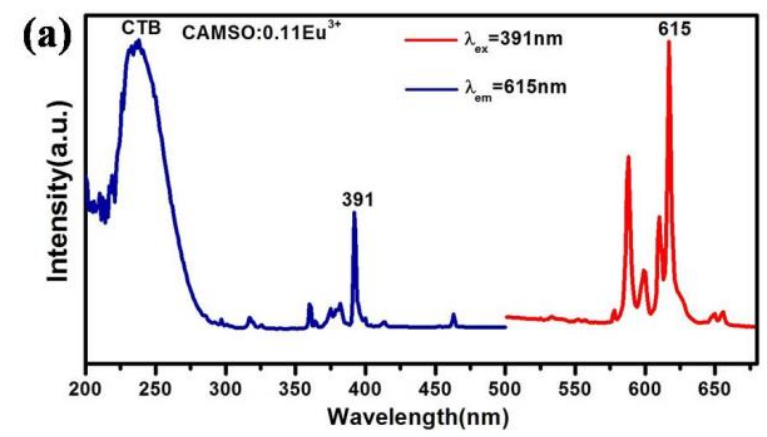

(b)

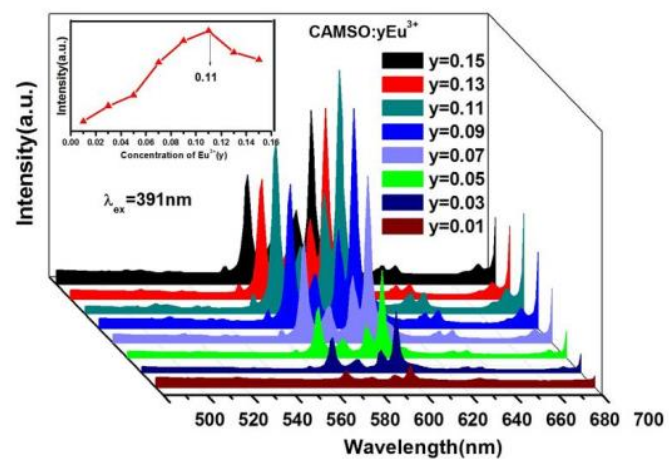

Figure 4: (a) The excitation and emission spectra of CAMSO:0.11Eu ${ }^{3+}$ sample (b) the emission spectra of CAMSO: $\mathrm{yEu}^{3+}(\mathrm{x}=0.01-0.15)$ samples, the inset exhibits the intensity of $\mathrm{Eu}^{3+}$ ion with different $\mathrm{Eu}^{3+}$ concentrations
Figure 4 a gives the excitation and emission spectra of CAMSO:11\% $\mathrm{Eu}^{3+}$ samples. From the figure, it can be found that the excitation spectrum monitored at $615 \mathrm{~nm}$ consists of a broad band from 200 to $300 \mathrm{~nm}$ and a sharp line with a maximum at $391 \mathrm{~nm}$. The broad band is attributed to the charge transfer (CT) band of $\mathrm{Eu}^{3+-} \mathrm{O}^{2-}$ and host and it may include the CT excitation of $\mathrm{Eu}^{3+}$ ions and the energy transfer transition from matrix to $\mathrm{Eu}^{3+}$ ions. More in-depth, the CT band is due to the transition of electron from the filled $2 p$ levels of oxygen to the $4 \mathrm{f}$ orbital of $\mathrm{Eu}^{3+}$. The narrow excitation peak at $391 \mathrm{~nm}$ is corresponding to the ${ }^{7} \mathrm{~F}_{0} \rightarrow{ }^{5} \mathrm{~L}_{6}$ transition of $\mathrm{Eu}^{3+}$. When excited at $391 \mathrm{~nm}$, the emission spectrum covering the region from 500 to $700 \mathrm{~nm}$ is obtained. In the spectrum, there are several emission bands at 576, 587, 615 and $653 \mathrm{~nm}$ which correspond to the characteristic f-f transitions of Eu ${ }^{3+}$, in detail, ${ }^{5} \mathrm{D}_{0} \rightarrow{ }^{7} \mathrm{~F}_{0},{ }^{5} \mathrm{D}_{0} \rightarrow{ }^{7} \mathrm{~F}_{1},{ }^{5} \mathrm{D}_{0} \rightarrow{ }^{7} \mathrm{~F}_{2}$ and ${ }^{5} \mathrm{D}_{0} \rightarrow{ }^{7} \mathrm{~F}_{3}$ respectively [27]. It is clearly observed that the strong emission ascribed to the ${ }^{5} \mathrm{D}_{0} \rightarrow{ }^{7} \mathrm{~F}_{2}$ electric dipole transition $(615 \mathrm{~nm})$ becomes strongest among all these peaks, indicating that the sites of $\mathrm{Eu}^{3+}$ ions is lack of inversion symmetry. Thereby, the red emission is often dominant in the emission spectrum and the phosphor CAMSO:11\% $\mathrm{Eu}^{3+}$ shows a bright red light under UV irradiation. The emission spectra of CAMSO: $\mathrm{y} \% \mathrm{Eu}^{3+}$ with different concentrations of $\mathrm{Eu}^{3+}$ are shown in Figure $4 \mathrm{~b}$. The explanation of the concentration quenching of $\mathrm{Eu}^{3+}$ ions is similar to $\mathrm{Dy}^{3+}$, please refer to Fig. $4 \mathrm{~b}$. The optimal doping contents of $\mathrm{Eu}^{3+}$ is determined to be $11 \%$.

In order to further study the tunable color luminescence and energy transfer in $\mathrm{Dy}^{3+}, \mathrm{Eu}^{3+}$ co-doped CAMSO host, the concentration of $\mathrm{Dy}^{3+}$ ions is fixed for $5 \mathrm{~mol} \%$, a optimized concentration which is chosen based on the results of the PL intensity of Dy ${ }^{3+}$-doped phosphors, a series of CAMSO: $5 \% \mathrm{Dy}^{3+}, \mathrm{y} \% \mathrm{Eu}^{3+}(\mathrm{y}=0,0.01-0.15)$ samples have been prepared and their PL spectra are compared in Figure $5 \mathrm{a}$. It can be seen that the emission spectra under the excitation of $344 \mathrm{~nm}$ contain the characteristic emissions for both $\mathrm{Dy}^{3+}$ and $\mathrm{Eu}^{3+}$ ions. As shown in Figure $5 \mathrm{a}$ and b, with the increasing of $\mathrm{Eu}^{3+}$ contents, the emission intensity of $\mathrm{Dy}^{3+}$ ions decrease while the emission intensity of $\mathrm{Eu}^{3+}$ ions increase, which implies that the $\mathrm{Eu}^{3+}$ ions emission is sensitized by Dy ${ }^{3+}$ ions through the energy transfer. When the $\mathrm{Eu}^{3+}$ concentration is beyond $11 \mathrm{~mol} \%$, the intensity of the $\mathrm{Eu}^{3+}$ emission begins to decrease due to the self-quenching effect which are the interactions between $\mathrm{Eu}^{3+}$ ions. The above results demonstrate that tunable color can be realized by adjusting the concentration of $\mathrm{Eu}^{3+}$ and the energy transfer from $\mathrm{Dy}^{3+}$ to $\mathrm{Eu}^{3+}$ exists in the CAMSO host.
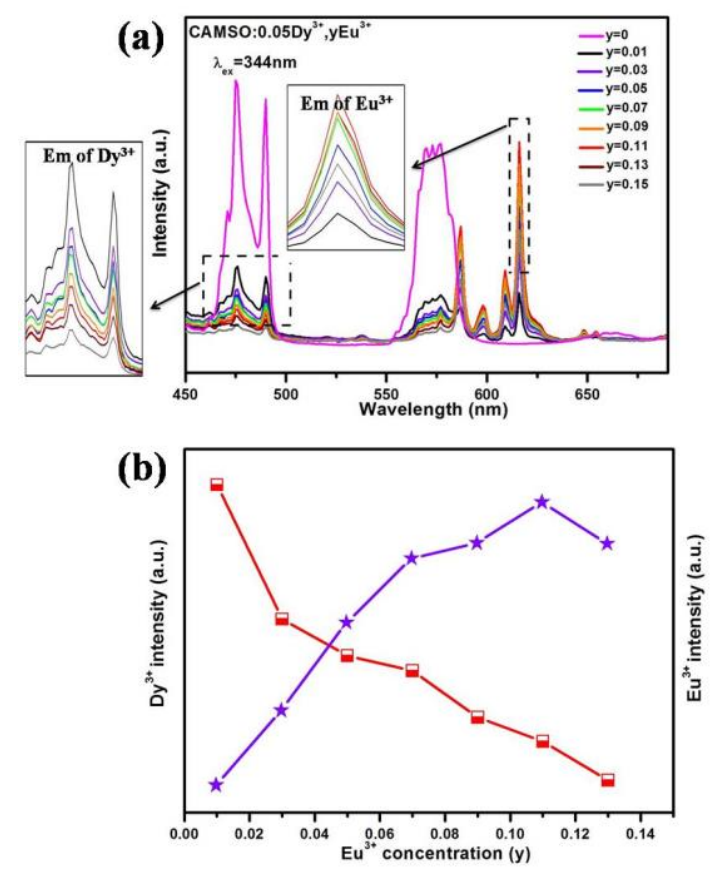

Figure 5: (a) Photoluminescence emission spectra of the CAMSO:0.05 $\mathrm{Dy}^{3+}, \mathrm{yEu}^{3+}(\mathrm{y}=0.01-0.13)$ samples with different $\mathrm{Eu}^{3+}$ doped concentrations (b) dependence of emission intensity on the $\mathrm{Eu}^{3+}$ concentration 
The CIE 1931 chromaticity coordinates diagram for CAMSO:5\% Dy $^{3+}$, $\mathrm{y} \% \mathrm{Eu}^{3+}$ phosphors measured at $344 \mathrm{~nm}$ is depicted in Figure 6. It can be seen that with the increasing $\mathrm{Eu}^{3+}$ concentration, the chromaticity coordinates value $(x, y)$ vary systematically from $(0.388,0.422)$ to $(0.511,0.267)$ because of the different emission components of the Dy ${ }^{3+}$ and $\mathrm{Eu}^{3+}$ ascribed to the energy transfer from $\mathrm{Dy}^{3+}$ to $\mathrm{Eu}^{3+}$. In addition, the corresponding color tone of the samples can change from yellow to orange red light by appropriately adjusting the relative content proportion of $\mathrm{Dy}^{3+}$ and $\mathrm{Eu}^{3+}$. The phosphors can realize multicolor emission from yellow to orange red light under the excitation with an UV wavelength of $344 \mathrm{~nm}$, which is accessible to UV LEDs. The above results indicate that the CAMSO: $\mathrm{Dy}^{3+}, \mathrm{Eu}^{3+}$ phosphor has potential application value in pc-white LEDs.

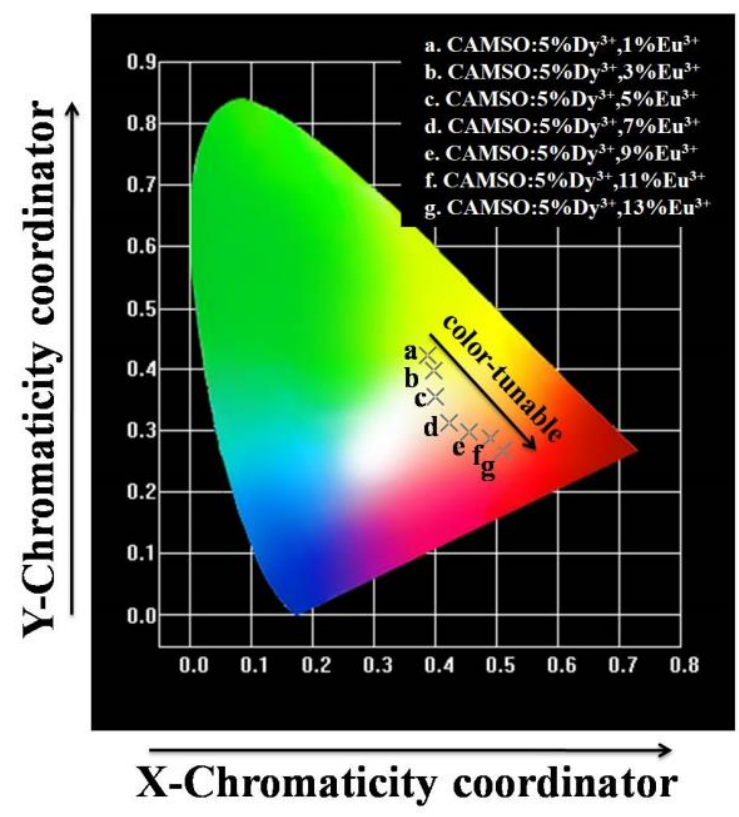

Figure 6: CIE chromaticity diagram of the selected CAMSO:0.05 $\mathrm{Dy}^{3+}, \mathrm{yEu}^{3+}$ phosphors under the UV excitation

\section{CONCLUSIONS}

In general, a series of $\mathrm{Dy}^{3+}$ and $\mathrm{Eu}^{3+}$ co-doped CAMSO phosphors have been synthesized by solid state reaction and the crystal structure, luminescent property, energy transfer and multicolor emission behavior were investigated in detail. The XRD analyses indicate that $\mathrm{Dy}^{3+}$ and $\mathrm{Eu}^{3+}$ are totally incorporated into the CAMSO host lattice. The energy transfer process of $\mathrm{Dy}^{3+} \rightarrow \mathrm{Eu}^{3+}$ has been confirmed in the CAMSO host by the excitation and emission spectra. In addition, the emission color can be tuned from yellow to orange red by adjusting appropriate concentration of $\mathrm{Dy}^{3+}$ and $\mathrm{Eu}^{3+}$ ions the above results indicate that the single-component phosphors exhibiting color-tunable emissions may have potential application value in pc-white LEDs.

\section{ACKNOWLEDGMENTS}

This present work is financially supported by the Major Program for the Field, Jilin Chemical Engineering University.

\section{REFERENCE}

[1] Chengaiah, T., Jayasankar, C.K., Babu, A.M., Moorthy, L.R. 2014. Eu ${ }^{3+-}$ $\mathrm{Dy}^{3+}$ co-doped $\mathrm{Na}_{3} \mathrm{Gd}_{(}\left(\mathrm{PO}_{4}\right)_{2}$ phosphors for white light luminescence. Mater. Express, 4, 153-158. doi: 10.1166/mex.2014.1149

[2] Yin, W.Y., Zhou, L.J., Gu, Z.J., Tian, G., Jin, S., Yan, L., Liu, X.X., Xing, G., Ren, W. 2012. Lanthanide-doped $\mathrm{GdVO}_{4}$ up conversion nanophosphors with tunable emissions and their applications for biomedical imaging. Journal of Materials Chemistry C, 22, 6974-6981. doi: 10.1039/C2JM16152D

[3] Wang, X.F., Yang, Q., Wang, G.G., Wang, X.Z. 2016. A new singlecomponent $\mathrm{KCaY}(\mathrm{PO} 4)_{2}: \mathrm{Dy}^{3+}, \mathrm{Eu}^{3+}$ nanosized phosphor with high colorrendering index and excellent thermal resistance for warm-white NUVLED. RSC. Adv, 6, 96263-96274. doi: 10.1039/C6RA20912B
[4] Babu, B.H., Kumar, R.K.V.V. 2014. Photoluminescence properties and energy transfer in $\gamma$-irradiated $\mathrm{Dy}^{3+}, \mathrm{Eu}^{3+}$-codoped fluoroaluminoborate glasses. Journal of Materials Science, 49, 7959-7969. doi: 10.1007/s1085

[5] Xie, R.J., Hirosaki, N., Mitomo, M., Takahashi, K., Sakuma, K. 2006. Highly efficient white-light-emitting diodes fabricated with short-wavelength yellow oxynitride phosphors. Applied Physics Letters, 88, 101-104. doi: $10.1063 / 1.2182067$

[6] Tang, W.J., Zhang, F. 2014. A single-phase emission-tunable $\mathrm{Ca}_{5}\left(\mathrm{PO}_{4}\right)_{3}$ $\mathrm{F}: \mathrm{Eu}^{2+}, \mathrm{Mn}^{2+}$ phosphor with efficient energy transfer for white LEDs. European Journal of Inorganic Chemistry, 3387-3392. doi: 10.1002/ejic.201402187

[7] Zhang, F., Tang, W.J. 2015. Synthesis and luminescence properties of $\mathrm{Ca}_{8} \mathrm{NaGd}\left(\mathrm{PO}_{4}\right)_{6} \mathrm{~F}_{2}: \mathrm{Eu}^{2+}, \mathrm{Mn}^{2+}$ for white LEDs. Optical Materials, 627, 218221. doi: $10.1016 /$ j.optmat.2014.07.022

[8] Xuan, Y., Wang, X.F., Liu, C.S., Yan, X.H. 2014. Structure and Luminescence Properties of Single-Phased $\mathrm{BaCa}_{2} \mathrm{Y}_{6} \mathrm{O}_{12}: \mathrm{Eu}^{3+}$, Dy ${ }^{3+}$. Journal of Solid State Science and Technology, 3, R216-R211. doi: $10.1149 / 2.0011412$ jss

[9] Dutta, S., Sharma, S.K. 2016. Energy transfer between $\mathrm{Dy}^{3+}$ and $\mathrm{Eu}^{3+}$ in $\mathrm{Dy}^{3+} / \mathrm{Eu}^{3+}$-codoped $\mathrm{Gd}_{2} \mathrm{MoO}_{6}$. Journal of Materials Science, 51, 6750-6760. doi: $10.1007 / \mathrm{s} 1085$

[10] Song, Y., Shao, B.Q., Feng, Y., Lv, W., Liu, G.X., You, H.P. 2016. A novel strategy to enhance the luminescence performance of $\mathrm{NaGdF}_{4}: \operatorname{Ln}^{3+}$ nanocrystals. Dalton. Trans, 45, 9468-9476. doi: 10.1039/c6dt01206j

[11] Pavitra, E., Seeta Rama Raju, G., Yu, J.S. 2013. White light emission from $\mathrm{Eu}^{3+}$ co-activated $\mathrm{Ca}_{2} \mathrm{Gd}_{8} \mathrm{Si}_{6} \mathrm{O}_{26}: \mathrm{Dy}^{3+}$ nanophosphors by solvothermal synthesis. Ceramics International, 39, 6319-6324. doi: 10.1016/j.ceramint.2013.01.057

[12] Zhou, Y., Xu, J.Y., Zhang, Z.J., You, M.J. 2014. The spectroscopic properties of $\mathrm{Dy}^{3+}$ and $\mathrm{Eu}^{3+}$ co-doped $\mathrm{ZnWO}_{4}$ phosphors. Journal of Alloys and Compounds, 615, 624-628. doi: 10.1016/j.jallcom.2014.07.075

[13] Kim, J.S., Jeon, P.E., Choi, J.C., Park, H.L., Mho, S.J., Kim, G.C. 2004. Warm- white-light emitting diode utilizing a single-phase full-color $\mathrm{Ba}_{3} \mathrm{MgSi}_{2} \mathrm{O}_{8}: \mathrm{Eu}^{2+}, \mathrm{Mn}^{2+}$ phosphor. Applied Physics Letters, 84, 231909231909-3. doi: 10.1063/1.1695441

[14] Zhang, Z., Mao, Z. Song, S., Zhang, J., Liu, L. Zhang, W., Wang, D. 2013. Preparation and investigation of $\left(\mathrm{Sr}_{0.85} \mathrm{Mg}_{0.14}\right)_{3}\left(\mathrm{P}_{1-\mathrm{x}} \mathrm{Si}_{\mathrm{x}} \mathrm{O}_{4}\right)_{2}$ : Dy ${ }^{3+}$ singlephase full-color phosphor. Materials Letters, 90, 1-3. doi: 10.1016/j.matlet.2012.08.144

[15] Kang, F.W., Yang, X.B., Peng, M.Y., Wondraczek, L., Ma, Z.J., Zhang, Q.Y., Qiu, J.R. 2014. Red Photoluminescence from $\mathrm{Bi}^{3+}$ and the Influence of the Oxygen-Vacancy Perturbation in $\mathrm{ScVO}_{4}$ : A Combined Experimental and Theoretical Study. The Journal of Physical Chemistry C, 118, 7515-7522. doi: $10.1021 /$ jp 4081965

[16] Blasse, G. 1966. On the Eu ${ }^{3+}$ Fluorescence of Mixed Metal Oxides. IV. The Photoluminescent Efficiency of $\mathrm{Eu}^{3+}$-Activated Oxides. The Journal of Chemical Physics, 45, 2356-2360. doi: 10.1063/1.1727946

[17] Deng, Y.M., Yi, S.P., Huang, J., Xian, J.Q., Zhao, W.R. 2014. White light emission and energy transfer in $\mathrm{Dy}^{3+} / \mathrm{Eu}^{3+}$ co-doped $\mathrm{BaLa}_{2} \mathrm{WO}_{7}$ phosphors. Materials Research Bulletin, 57, 85-90. doi: 10.1016/j.materresbull.2014.05.035

[18] Il Jeon, Y., Krishna Bharat, L., Yu, J.S. 2015. Synthesis and luminescence properties of $\mathrm{Eu}^{3+} / \mathrm{Dy}^{3+}$ ions co-doped $\mathrm{Ca}_{2} \mathrm{La}_{8}\left(\mathrm{GeO}_{4}\right)_{6} \mathrm{O}_{2}$ phosphors for white-light applications. Journal of Alloys and Compounds, 620, 263-268. doi: 10.1016/j.jallcom.2014.09.135

[19] Guo, C., Luan, L., Huang, D., Su, Q., Lv, Y. 2007. Study on the stability of phosphor $\mathrm{SrAl}_{2} \mathrm{O}_{4}: \mathrm{Eu}^{2+}, \mathrm{Dy}^{3+}$ in water and method to improve its moisture resistance. Materials Chemistry and Physics, 106, 268-272. doi: 10.1016/j.matchemphys.2007.05.052

[20] Parchur, A.K., Prasad, A.I., Rai, S.B., Ningthoujam, R.S. 2012. Improvement of blue, white and NIR emissions in $\mathrm{YPO}_{4}: \mathrm{Dy}^{3+}$ nanoparticles on co-doping of $\mathrm{Li}^{+}$ions. Dalton Trans, 41, 13810. doi: $10.1039 / \mathrm{c} 2 \mathrm{dt} 32062 \mathrm{~b}$

[21] Yuan, B., Song, Y.H., Sheng, Y., Zheng, K., Zhou, X., Ma, P.C., Xu, X., Zou, H.F. 2015. Tunable color and energy transfer in single-phase white- 
emitting $\mathrm{Ca}_{20} \mathrm{Al}_{26} \mathrm{Mg}_{3} \mathrm{Si}_{3} \mathrm{O}_{68}: \mathrm{Ce}^{3+}$, Dy ${ }^{3+}$ phosphors for UV white lightemitting diodes. Journal of Solid State Chemistry, 232, 169-177. doi: 10.1016/j.jssc.2015.09.015

[22] Liu, Y., Liu, G., Dong, X., Wang, J., Yu, W. 2015. Tunable photoluminescence and magnetic properties of $\mathrm{Dy}^{3+}$ and $\mathrm{Eu}^{3+}$ doped $\mathrm{GdVO}_{4}$ multifunctional phosphors. Physical Chemistry Chemical Physics, 17, 26638-26644. doi: 10.1039/c5cp04373e

[23] Li, K., Fan, J., Mi, X.Y., Zhang, Y., Lian, H.Z., Shang, M.M., Lin, J. 2014. Tunable-color luminescence via energy transfer in $\mathrm{NaCa}_{13 / 18} \mathrm{Mg}_{5} /{ }_{18} \mathrm{PO}_{4}$ : A $\left(\mathrm{A}=\mathrm{Eu}^{2+} / \mathrm{Tb}^{3+} / \mathrm{Mn}^{2+}, \mathrm{Dy}^{3+}\right)$ phosphors for solid state lighting. Inorganic Chemistry, 53, 12141-12150. doi: 10.1021/ic502058r

[24] Gai, S., Li, C., Yang P., Lin, J. 2014. Recent Progress in Rare Earth Micro/Nanocrystals: Soft Chemical Synthesis, Luminescent Properties, and Biomedical Applications. Chemical Reviews, 114, 2343-2389. doi: 10.1021/es803431c

[25] Puppalwar, S.P., Dhoble, S.J. 2015. Photoluminescence properties of $\mathrm{LiBaPO}_{4}: \mathrm{M}^{3+}$ phosphor for near-UV light-emitting diode (M = Eu and Dy). Luminescence, 30, 745-750. doi: 10.1002/bio.2815

[26] Chan, T.S., Lin, C.C., Liu, R.S., Xie, R.J., Hirosaki, N., Cheng, B.M. 2009. Photoluminescent and thermal stable properties of $\mathrm{Tb}^{3+}$-doped Ca-alphaSiAlON under VUV excitation. Journal of The Electrochemical Society, 156, J189-J191. doi: 10.1149/1.3125135

[27] Min, X., Huang, Z., Fang, M., Liu, Y.G., Tang C., Wu, X. 2014. Energy Transfer from $\mathrm{Sm}^{3+}$ to $\mathrm{Eu}^{3+}$ in Red-Emitting Phosphor LaMgAl ${ }_{11} \mathrm{O}_{19}: \mathrm{Sm}^{3+}$, $\mathrm{Eu}^{3+}$ for Solar Cells and Near-Ultraviolet White Light-Emitting Diodes. Inorganic Chemistry, 53, 6060-6065. doi: 10.1021/ic500412r. 